\title{
Dr. Shu Hyun Yoon
}

$\mathrm{T}$

he urological community recently lost Dr. Shu Hyun Yoon of Dartmouth, NS, at the age of 89. He passed away peacefully at home on May 30, 2018. Dr. Yoon is survived by his sons, Robert (Beverley) and Michael (Sandra), as well as his grandchildren, Christopher, Stephanie, Jacob, Joshua, and Daniel, and many members of his extended family.

He was predeceased by his beloved wife, Suk.

Originally from North Korea, Dr. Yoon lived in Dartmouth for many years, working as a urologist at the Halifax Infirmary, Camp Hill, Dartmouth General Hospitals, and in private practice.

He was an active member of the Halifax Korean Church and the Atlantic School of Theology, as well as a published author. He will be remembered fondly by all those whose life he touched.

Cite as: Can Urol Assoc J 2018;12(8):288. hitp://dx.doi.org/10.5489/cuai.5528

\section{Dr. Roméo Charrois}

T

he CUA recently learned of the passing of Dr. Roméo Charrois, who died May 13, 2017, at the age of 82. He left behind his wife, Dr. Marie Dubreuil, children, Michel (Tany), Hélène, Marie-Josée, Geneviève (Frédéric), and Sophie, grand-children Béatrice, Dominic, Émilie, Nicolas, Louis, Myriam, Samuel, Alexandre, Jonathan, Samantha, Maxime, Erwan, Morgane, Gwenaëlle, Cédric, and Thomas, and countless other extended family and friends.

A long-time practicing urologist in Quebec, Dr. Charrois will be missed by his family, his many patients, and the entire urological community. 